\title{
STRATEGIJE ODGOJITELJICE U FACILITIRANJU SOCIJALNIH INTERAKCIJA DJECE U VRTIĆU
}

\author{
Vlatka Družinec \\ Sveučilište u Rijeci \\ Filozofski fakultet u Rijeci \\ doktorandica na Doktorskom studiju Pedagogije
}

Doris Velan

Sveučilište Jurja Dobrile u Puli

Fakultet za odgojne i obrazovne znanosti

\section{Sažetak}

Od najranijih dana života djeca u obitelji usvajaju socijalne vještine potrebne za djelotvornu socijalnu interakciju, a odgojitelji u vrtiću organiziraju programske aktivnosti, stvaraju poticajno i ugodno ozračje za njihovo učenje i uvježbavanje. Odgojno-obrazovnim strategijama odgojitelj potiče socijalne interakcije djece u vrtiću i svojim vlastitim karakteristikama ponašanja pruža model za razvoj njihovih socijalnih vještina.

Cilj je istraživanja utvrditi kojim se strategijama koristi odgojiteljica u facilitiranju socijalnih interakcija djece u vrtiću. Istraživanje je provedeno tijekom veljače, ožujka, travnja i svibnja 2017. godine, na uzorku od jedne odgojiteljice u Dječjem vrtiću „Olga Ban“ u Pazinu. U istraživanju su korištena dva mjerna instrumenta: Protokol nesudioničkog opažanja, izrađen za potrebe ovoga istraživanja kojim su se evidentirale strategije odgojiteljice i Polustruktuirani upitnik za refleksiju odgojiteljice. Sukladno dogovoru s odgojiteljicom, promatrač je boravio u odgojno-obrazovnoj skupini dvadesetak puta i u tri različite vremenske točke trajanja pet 
minuta: 8:35 (vrijeme doručka), 9:20 (vrijeme jutarnjega kruga), 10:05 (podjela materijala i aktivnosti) opažao i bilježio strategije odgojiteljice. Nakon obrade podataka iz protokola praćenja ponašanja odgojiteljice i interpretacije, proveden je razgovor s odgojiteljicom čije je ponašanje opažano s ciljem njezine refleksije na dobivene rezultate.

Rezultati istraživanja pokazuju da odgojiteljica u većini situacija razgovara s djecom koja su u sukobu, ne kažnjava, daje prijedloge $\mathrm{u}$ socijalnim interakcijama, a ne naredbe, postavlja pitanja sa zanimanjem za dječje mišljenje, uvažava dječje zamisli i potiče djecu na izražavanje svojih želja, potiče djecu na suradnju i predlaže rečenice za poticanje suradnje, osigurava alternativu tužakanju, potiče djecu na strpljenje, potiče altruizam i empatiju, potiče alternativne interpretacije tuđega ponašanja, potiče djecu da postavljaju pitanja i koristi se uljudnim frazama u razgovoru s djecom. Tijekom refleksije odgojiteljica je iskazala zadovoljstvo korištenim metodama i istaknula dobrobit istraživanja za daljnji rad i planiranje aktivnosti.

Ključne riječi: odgojitelj, strategija, socijalna interakcija, socijalne vještine 


\section{Uvod}

Socijalizacija djece počinje od najranijih dana života u interakcijama s članovima najuže obitelji. Dijete promatranjem i identifikacijom s članovima obitelji izgrađuje sustav vrijednosti, usvaja navike i ponašanja, stoga su roditelji prvi i najvažniji odgojitelji djece, a Berk (2008) tvrdi da se po snazi i opsegu utjecaja niti jedan drugi sustav ne može mjeriti s obitelji. Tijekom primarne socijalizacije dijete usvaja i uvježbava vještine koje su mu potrebne za stvaranje odnosa s okolinom, a uključuju suradnju, uvažavanje drugih, sociocentričnost (Janković et al., 1995), prepoznavanje i razumijevanje vlastitih i tuđih emocionalnih stanja, empatiju, altruizam (Brajša-Žganec, Slunjski, 2007) i sl. Uključivanjem djeteta u predškolske ustanove nastavlja se proces socijalizacije. Naime, kroz igru i druženje s vršnjacima djeca uče rješavati probleme i pregovarati, dijeliti stvari, čekati na red, sudjelovati u grupnim aktivnostima, susreću se s pitanjima pravde i pravednosti te usvajaju pravila ponašanja (Logue, 2007).

Dobri odnosi s članovima obitelji i vršnjacima preduvjet su za stvaranje kvalitetnih odnosa u kasnijim godinama života i stvaranje socijalnih kompetencija za život i rad u društvu. Cilj socijalizacije u obitelji, društvu i dječjem vrtiću je socijalno kompetentno dijete, koje je ovladalo socijalnim vještinama i primjenjuje prosocijalne oblike ponašanja. Osim obitelji, vršnjaka i odgojno-obrazovnih ustanova suvremena shvaćanja socijalizacije naglašavaju i aktivnost pojedinca u tom procesu (Matijević et al., 2016).

Socijalne kompetencije razvijaju se u interakciji s drugima (Katz, McClellan, 1999), a podrazumijevaju ponašajne, kognitivne i emocionalne varijable u kreiranju pozitivnih socijalnih odnosa (Žižak, 2003). Sastavnice socijalne kompetencije su: empatija, komunikacijske vještine, tolerancija, kooperativnost $i$ uzajamna pomoć, odgovornost prema sebi $i$ drugima, upornost u obavljanju zadataka, odgoda zadovoljstva, kontrola nasilnih ponašanja, iskazivanje osjećaja vrijednosti, jedinstvenost $i$ pozitivna slika o sebi (Mlinarević, Tomas, 2010). Kod djece u vrtiću se socijalna kompetencija odnosi na razinu prihvaćanja/odbacivanja od strane vršnjaka, a ovisi o sposobnosti djeteta za iniciranje interakcije i održavanje odnosa s vršnjacima (Katz, McClellan, 1999; Mlinarević, Tomas, 2010). Vršnjački 
status/popularnost i prijateljstvo su dva aspekta socijalne kompetentnosti. Vršnjački status odražava simpatiziranje od strane vršnjaka, dok je prijateljstvo uzajamni odnos dvoje djece. Pritom je važnost prijateljstva veća jer kao bliski odnos dvoje djece pridonosi djetetovom mentalnom zdravlju i razvoju kvalitete života. Socijalno kompetentno dijete rabi vlastite socijalne mogućnosti i poticaje iz okoline u postizanju uključenosti i funkcioniranja unutar grupe (Katz, McClellan, 1999), aktivna su u interakciji s vršnjacima i odraslima te tako unapređuju svoje razvojne potencijale.

Sastavni dio socijalnih kompetencija jesu socijalne vještine. Pojam socijalnih vještina odnosi se na ponašajnu stranu socijalne kompetentnosti, a podrazumijeva različite oblike specifičnih ponašanja: interpersonalna ponašanja, ponašanja usmjerena na ostvarenje određenog zadatka i ponašanja usmjerena prema sebi (Žižak, 2003). Socijalne vještine djece iskazuju se u okviru njihovih socijalnih kompetencija, odnosno, u iskazivanju djetetovih reakcija na oblike ponašanja njegovih vršnjaka (Katz, McClellan, 1999). Djeca mogu biti socijalno kompetentna (Tatković et al., 2016) ako se na prikladan način koriste socijalnim vještinama i istovremeno uspješno postižu osobne ciljeve. Za razvoj dobrih socijalnih odnosa vrlo je važan i razvoj komunikacijskih sposobnosti (Tatković et al., 2016).

\section{Uloga odgojitelja/odgojiteljice u razvoju socijalne kompetencije djece u vrtiću}

Socijalne kompetencije djece pridonose stvaranju bolje slike o sebi i uspostavljanju kvalitetnijih odnosa s drugima, što doprinosi psihološkom zdravlju djeteta, a unapređuju se vježbanjem (Brdar, 1994). U poticanju i razvoju socijalnih vještina djece u vrtiću najvažniju ulogu ima odgojitelj/odgojiteljica, koji posjeduje pedagoške kompetencije vezane uz promišljanje i oblikovanje metodičkih postupaka u radu s djecom (Lučić, 2007). Odgojitelj/odgojiteljica organizira okolinu u vrtiću, stvara atmosferu za pozitivne socijalne interakcije, potiče djecu na aktivnost i verbaliziranje mišljenja u rješavanju problema (Hohmann, Weikart, 2005 prema Lepičnik Vodopivec, 2011), komunicira s djecom s ciljem prepoznavanja specifičnih dječjih interesa i vještina te pružanja adekvatne stimulacije (Lepičnik Vodopivec, 2011), promatra dječje ponašanje, uočava obrasce i razumije 
ih te nastoji pravilno reagirati na odgojne izazove u skladu s načelima razvoja djeteta. Kada djeluju u sinergiji - odnosi, okolina i igra, stvaraju poticajno okruženje za društveni i emocionalni razvoj djeteta u vrtiću (Kirk, MacCallum, 2017).

Pozitivan odnos djece i odgojitelja važan je za razvoj socijalne kompetencije djece i njihovu uključenost u skupinu (Hamre, Pianta, 2001 prema Demirkaya, Bakkaloglu, 2015), a interakcija djece i odgojitelja je primarni mehanizam za razvoj i učenje u vrtiću (Brophy-Herb et al., 2007 prema Kirk, MacCallum, 2017). Interakcija odgojitelja i djeteta je model za razvoj socijalne kompetencije kod djece. U socijalno zahtjevnim situacijama u vrtiću, socijalne vještine odgojitelja preduvjet su uspješnoga i djelotvornoga rada. Odgojitelj koji sam nije u potpunosti ovladao socijalnim vještinama teško će pomoći djeci u razvoju istih. Jedna od glavnih karakteristika odgojitelja koji će svojim ponašanjem utjecati na pozitivni razvoj socijalnih kompetencija kod djece jest empatija. Empatični odgojitelj uvažava i poštuje dječje osjećaje, potiče izražavanje emocija i poriva, stvara prilike za jačanje dječje empatije i altruizma, pomaže u razumijevanju posljedica eventualnih agresivnih postupaka djece (Ivon, Sindik, 2008). U istraživanju povezanosti odgojiteljičine emocionalne empatije i mašte s prosocijalnim i agresivnim ponašanjem djece utvrđeno je kako su djeca iz odgojnih skupina koje vode više empatične i maštovite odgojiteljice procijenjena kao više prosocijalna u odnosu na djecu koju vodi manje empatična i maštovita odgojiteljica, koja su procijenjena kao više agresivna (Ivon, Sindik, 2008).

Odgojitelji/odgojiteljice ne podučavaju djecu socijalnim vještinama neposrednim podučavanjem, već su strategije podučavanja uglavnom usmjerene na individualno vođenje djeteta, eksplicitno poučavanje (Logue, 2007) i facilitiranje socijalnih interakcija djece od strane odgojitelja. Naime, malo dijete će obratiti veću pozornost aktivnosti ukoliko je izravno uključeno te će pozornije slušati i reagirati na prijedloge odgojitelja (Katz, McClellan, 1999).

Djeca stječu socijalne kompetencije unutar konteksta u kojem se osjećaju sigurno i vrijedno kao pojedinci (Logue, 2007), stoga se odgojitelji u radu vode načelima pedagoške prakse koja pojačavaju socijalnu kompetenciju djece. Katz i McClellan (1999) navode devet generalizacija 
kojima se koriste odgojitelji za donošenje odluka u radu s djecom: 1) dječji osjećaji su važni, 2) socijalna kompetencija je kulturološki određena, 3) teškoće u socijalizaciji su prigoda za pouku, 4) socijalno ponašanje se razvija u zatvorenome krugu, 5) izravna komunikacija pojačava djelotvornost odraslih, 6) važni odnosi zahtijevaju suzdržanost, 7) optimalna intervencija odgojitelja potiče socijalnu kompetenciju, 8) očekivanja odraslih oblikuju dječje karaktere, 9) interakcija odgojitelja i učitelja s djecom model je socijalne kompetencije.

Iako ne postoji recept za djelotvorno odgojno-obrazovno ponašanje odgojitelja, u literaturi se nalazi niz strategija koje pojačavaju, odnosno, onih koje su kontraproduktivne u radu s djecom na razvoju njihovih socijalnih kompetencija. Katz i McClellan (1999) sastavili su popis djelotvornih strategija kojima odgojitelji promiču dječju socijalnu kompetenciju i unapređuju pozitivno okruženje u vrtiću, a podrazumijeva otvorenu komunikaciju s roditeljima, poštivanje dječjih osjećaja, uspostavljanje autoriteta i povjerenja, pozitivno „etiketiranje“ dječjih karaktera, poboljšano ovladavanje porivima, uvažavanje individualnih razlika, pozivanje na temeljna pravila, pojačavanje prosocijalnoga umijeća, obraćanje dječjem zdravom razumu te pomoć djeci u prevladavanju nedaća.

Socijalne interakcije djece u vrtiću prilika su za učenje socijalnih vještina i pojačavanje socijalnih kompetencija. Iako je ponekad dobro ostaviti djecu da samostalno istražuju svoju socijalnu okolinu i nastoje pronaći mjesto za sebe, u pojačavanju sastavnica socijalne kompetencije aktivna uloga odraslih je nezaobilazna (Slunjski, 2013). U vrtiću su odgojitelji ti koji će strategijama facilitirati uključivanje djece u suradničke i kreativne aktivnosti te potaknuti iniciranje i održavanje uspješnih odnosa između djece. U istraživanju uvjeta za kooperativno učenje i strategija podrške u vrtiću (Lepičnik Vodopivec, 2011), utvrđeno je kako prikladno opremljen prostor vrtića, dizajniran prema dječjem ukusu, opremljen igralištima i materijalima pruža izvrsne uvjete za stvaranje radne atmosfere. Odgojitelji prate i potiču djecu u njihovim aktivnostima, razmatraju njihove interese i inicijative te o njima promišljaju, pružaju smjernice ako je to nužno uz određenu dozu nezavisnosti, uređuju prostor, uspostavljaju ozračje pozitivne socijalne interakcije, dakle, koriste se različitim strategijama kojima podržavaju suradničko učenje kod djece (Lepičnik 
Vodopivec, 2011).

U ovome istraživanju polazi se od strategija i postupaka koje upotrebljavaju odgojitelji za pojačavanje socijalne kompetencije djece $\mathrm{u}$ vrtiću (Katz, McClellan, 1999), a kojima odgojitelji facilitiraju socijalne interakcije djece. Skretanjem pozornosti djece na tuđe osjećaje i interese (1) potiče se kod djece predviđanje reakcija i razumijevanje osjećaja drugih te bolje upoznavanje vršnjaka. Podsjećajući djecu na pravila ponašanja (2) odgojitelj jasno izražava svoja očekivanja glede poželjnog ponašanja djece (3), ograničenja i pravila koja vrijede jednako za sve. Pohvaljujući poželjno ponašanje (4) promiče se prosocijalno odgojno ozračje u skupini. Razgovorom s djecom (5) koja su u sukobu, a ne kažnjavanjem, djecu se potiče na usvajanje konstruktivnih obrazaca ponašanja u sukobima. Davanjem prijedloga (6), a ne naredbi, pokazuje se kako odgojitelj ima povjerenje u dječju prosudbu, a djeca tako ostvaruju pravo na izbor. Postavljanjem pitanja sa zanimanjem za dječje mišljenje (7), uvažavanjem dječjih zamisli (8) te poticanjem djece da izraze ono što žele (9), postavljanjem pitanja i ohrabrivanjem, pokazuje se djetetu da je njegovo mišljenje važno i vrijedno pažnje. Poticanjem djece na suradnju (10) $i$ ukazivanjem na prednosti i dobrobiti suradnje s drugom djecom, predlaganjem rečenica za poticanje suradnje (11) te ohrabrivanjem uključivanja u igru s drugom djecom (12), potiče se djecu na suradnju s drugima i vježbanje socijalnih odnosa.

Poticanje isprike (13) za neprimjerena ponašanja, osiguravanje alternative tužakanju (14) i poticanje djeteta da samo podsjeti drugu djecu na pravila ponašanja te poticanje djece na strpljenje (15) u aktivnostima koje zahtijevaju naizmjenično uključivanje, neke su od strategija usmjeravanja dječjega ponašanja u konfliktnim situacijama.

Poticanje empatije i altruizma (16) te alternativnih interpretacija tuđeg ponašanja (17) s ciljem uočavanja, poštivanja i prihvaćanja međusobnih razlika, strategije su koje pridonose boljem razumijevanju među djecom, razumijevanju tuđih osjećaja i ponašanja.

Poticanje otkrivanja i razgovora o zajedničkim interesima (18) djece ukazivanjem na iskustva ili interese koji su djeci zajednički, predlaganje tema za razgovor (19) i poticanje djece da postavljaju pitanja (20) te korištenje uljudnih fraza (21) u razgovoru s djecom strategije su kojima se daje djeci do znanja koliko su nam važni i koliko ih cijenimo. 


\section{Metodologija istraživanja}

Svrha ovoga istraživanja je utvrditi strategije odgojiteljice u facilitiranju socijalnih interakcija u vrtićkoj skupini kako bi se mogle dati preporuke za unapređenje rada. Cilj je istraživanja evidentirati kojim se strategijama koristi odgojiteljica u facilitiranju socijalnih interakcija djece u vrtiću. Istraživanje je provedeno sudioničkim promatranjem rada jedne odgojiteljice Dječjega vrtića „Olga Ban“ u Pazinu od veljače do svibnja 2017. godine. Ispitanica, odgojiteljica M. Č., ima 57 godina i 37 godina rada u struci te je odgojiteljica mješovite odgojno-obrazovne skupine, koja uključuje djecu od treće do sedme godine.

\section{Mjerni instrument}

$\mathrm{U}$ istraživanju su se koristila dva mjerna instrumenta. Prvi je Protokol nesudioničkog opažanja, izrađen za potrebe ovoga istraživanja kojim su se evidentirale strategije odgojiteljice prema modelu Katz, L. G. i McClellan, D. E. (1999). Drugi mjerni instrument je Polustrukturirani upitnik za refleksiju odgajateljice. Kako bi se pratilo koje strategije rabi odgojiteljica u facilitiranju socijalnih interakcija djece, u točno određenim vremenskim točkama, opažanje se temeljilo na smjernicama za pojačavanje pojedine sastavnice socijalne kompetencije u školi prema Katz, L. G. i McClellan, D. E. (1999) prilagođenim ovom istraživanju. Prilikom promatranja promatraču je ponuđeno rangirati svoje opažanje o korištenju strategija odgojiteljice u facilitiranju socijalnih interakcija djece u vrtiću zaokružujući riječ: DA (ako se ponašanje javilo u vremenskoj točki), NE (ako se ponašanje nije javilo u vremenskoj točki) i NIJE PROCJENJIVO (ako iz određenih razloga nije bilo moguće procijeniti korištenje strategija odgojiteljice).

Formular Protokola nesudioničkog opažanja odgojitelja u odgojnoobrazovnoj skupini se sastojao od zaglavlja u kojem su navedeni opći podaci o ustanovi i odgojitelju (dob, spol, radni staž) kojega se promatra te datum i vrijeme ispitivanja. Formular se sastoji od 21 čestice koje se odnose na strategije kojima se koristi odgojiteljica u facilitiranju socijalnih interakcija djece u dječjem vrtiću: 
- skreće pozornost djece na tuđe osjećaje i interese,

- podsjeća djecu na pravila ponašanja,

- jasno izražava svoja očekivanja glede poželjnog ponašanja djece,

- pohvaljuje poželjno ponašanje,

- razgovara s djecom koja su u sukobu, ne kažnjava,

- daje prijedloge, ne naredbe,

- postavlja pitanja sa zanimanjem za dječje mišljenje,

- uvažava dječje zamisli,

- potiče djecu da izraze ono što žele,

- potiče djecu na suradnju,

- predlaže rečenice za poticanje suradnje,

- ohrabruje dijete da se uključi u igru s drugom djecom,

- potiče isprike,

- osigurava alternativu tužakanju,

- potiče djecu na strpljenje,

- potiče empatiju i altruizam,

- potiče alternativne interpretacije tuđeg ponašanja,

- potiče djecu na otkrivanje i razgovor o zajedničkim interesima,

- predlaže teme za razgovor,

- potiče djecu da postavljaju pitanja,

- služi se uljudnim frazama u razgovoru s djecom.

Drugi mjerni instrument je Polustrukturirani upitnik za refleksiju odgojiteljice sa sljedećim pitanjima:

- Što mislite o rezultatima istraživanja koji se odnose na strategije kojima se koristite u facilitiranju socijalnih interakcija djece u dječjem vrtiću?

- Kojim rezultatima ste zadovoljni? Kojim rezultatima ste manje zadovoljni?

- Kako Vam se svidjelo provedeno istraživanje i u čemu Vam je pomoglo?

\section{Prikupljanje podataka}

Istraživanje je provedeno od veljače do svibnja 2017. godine s jednom odgojiteljicom Dječjega vrtića „Olga Ban“ u Pazinu. Sudjelovanje odgojiteljice je bilo dobrovoljno i unaprijed dogovoreno. Promatračica je boravila u odgojno-obrazovnoj skupini 20 puta u intervalu od 8:30 do 10:10. Prilikom boravka promatrala je kojim se strategijama koristi odgojiteljica u facilitiranju socijalnih interakcija između djece u vrtiću i bilježila opažena ponašanja u tri vremenske točke: 8:35 (vrijeme doručka), 9:20 (vrijeme 
jutarnjega kruga) i 10:05 (ponuda materijala i aktivnosti).

Nakon svih 20 boravaka u skupini, odgojiteljica je imala uvid $\mathrm{u}$ dobivene rezultate istraživanja i na temelju toga je napravila refleksiju na korištene strategije. Prisutnost promatračice nije remetila atmosferu i aktivnosti grupi jer je i prije boravila u skupini (kao pedagoginja toga vrtića) pa su djeca i odgojiteljice bile na nju već naviknuti. Prilikom promatranja $\mathrm{u}$ većini se vremenskih točaka moglo točno odrediti je li se neko ponašanje ostvarilo ili nije, iako vremenske točke nisu uvijek pratile ovu predviđenu strukturu s obzirom na to da je odgojno-obrazovni rad u dječjem vrtiću vrlo dinamičan, fleksibilan i poželjna su povremena odstupanja od dnevnoga rasporeda aktivnosti kako bi se sudjelovalo, učilo ili djelovalo u nekome projektu ili aktivnosti. Prije provedbe istraživanja odgojiteljica je upoznata s mogućnošću odustajanja od istraživanja, a roditelji djece su bili obaviješteni od strane odgojiteljice da će se u skupini provoditi istraživanje u kojem se promatra isključivo rad odgojiteljice, a ne njihove djece.

\section{Obrada podataka}

Prilikom obrade rezultata istraživanja zbrajale su se sve DA, NE i NIJE PROCJENJIVO strategije i interpretativni apsolutni brojevi, odnosno postotci. Nakon brojčane obrade i interpretacije, proveden je razgovor s odgojiteljicom čije je ponašanje promatrano s ciljem njezine refleksije na dobivene rezultate. Razgovor u trajanju od jednoga sata (60 minuta) s odgojiteljicom proveden je 30. svibnja 2016. u Dječjem vrtiću „Olga Ban“ u Pazinu. Razgovor je sniman, a kasnije je napravljen transkript. Nakon provedene refleksije odgojiteljica je imala uvid u svoju refleksiju i dala je suglasnost za njezino prikazivanje.

\section{Rezultati i rasprava}

Zbog preglednosti čestice su grupirane prema pojedinim strategijama za pojačavanje pojedinih sastavnica socijalne kompetencije (Katz, McClellan, 1999): produbljivanje socijalnih znanja i socijalnoga razumijevanja te pospješivanje interaktivnih umijeća. Specifičnim strategijama odgojitelji pomažu djeci u shvaćanju kako se njihovi vršnjaci 
razlikuju od njih samih prema iskustvima, željama, navikama i stajalištima, odnosno potiču kod djece socijalno razumijevanje i međusobno upoznavanje te uspostavljanje socijalnih odnosa s vršnjacima (Katz, McClellan, 1999).

\section{Produbljivanje socijalnih znanja}

Socijalna znanja podrazumijevaju poznavanje normi i pravila ponašanja grupe kojoj pojedinac pripada, a strategije kojima odgojitelji mogu produbljivati socijalno znanje jesu: podsjećanje djece na pravila ponašanja, jasno izražavanje očekivanja glede poželjnog ponašanja djece, pohvaljivanje poželjnog ponašanja, razgovor s djecom u sukobu, a ne kažnjavanje, davanje prijedloga, a ne naredbi.

Tablica 1. Korištenje strategija odgojiteljice za produbljivanje socijalnih znanja

\begin{tabular}{|c|c|c|c|c|c|}
\hline \multicolumn{2}{|l|}{ Čestica } & $\begin{array}{c}8: 35 \\
\text { (vrijeme } \\
\text { doručka) }\end{array}$ & $\begin{array}{c}9: 20 \\
\text { (vrijeme } \\
\text { jutarnjega } \\
\text { kruga) }\end{array}$ & 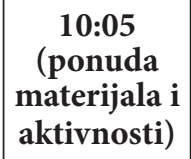 & Ukupno \\
\hline \multirow{2}{*}{$\begin{array}{l}\text { Podsjeća djecu na } \\
\text { pravila ponašanja (2) }\end{array}$} & $\mathrm{Da}$ & $8(53,33 \%)$ & $4(26,67 \%)$ & $3(20 \%)$ & $15(100 \%)$ \\
\hline & $\mathrm{Ne}$ & $11(22,45 \%)$ & $13(38,24 \%)$ & $10(29,41 \%)$ & $34(100 \%)$ \\
\hline \multirow{2}{*}{$\begin{array}{l}\text { Jasno izražava svoja } \\
\text { očekivanja glede } \\
\text { poželjnog ponašanja } \\
\text { djece (3) }\end{array}$} & $\mathrm{Da}$ & $8(42,11 \%)$ & $7(36,84 \%)$ & $4(21,05 \%)$ & $19(100 \%)$ \\
\hline & $\mathrm{Ne}$ & 10( & $11(3$ & $9(30$ & 30( \\
\hline \multirow{2}{*}{$\begin{array}{l}\text { Pohvaljuje poželjno } \\
\text { ponašanje (4) }\end{array}$} & $\mathrm{Da}$ & $3(16,67 \%)$ & $8(44,44 \%)$ & $7(38$ & $18(100 \%)$ \\
\hline & $\mathrm{Ne}$ & $14(46,67 \%)$ & $10(33,33 \%)$ & $6(20 \%)$ & $30(100 \%)$ \\
\hline \multirow{2}{*}{$\begin{array}{l}\text { Razgovara s djecom } \\
\text { koja su u sukobu, ne } \\
\text { kažnjava (5) }\end{array}$} & $\mathrm{Da}$ & $5(35,71 \%)$ & $7(50 \%)$ & $2(14,29 \%)$ & $14(100 \%)$ \\
\hline & $\mathrm{Ne}$ & 0 & 0 & 0 & 0 \\
\hline \multirow{2}{*}{$\begin{array}{l}\text { Daje prijedloge, ne } \\
\text { naredbe (6) }\end{array}$} & $\mathrm{Da}$ & $12(35,29 \%)$ & $13(38,24 \%)$ & $9(26,47 \%)$ & $34(100 \%)$ \\
\hline & $\mathrm{Ne}$ & $1(25 \%)$ & $2(50 \%)$ & $1(25 \%)$ & $4(100 \%)$ \\
\hline
\end{tabular}

Prema protokolu praćenja odgojiteljica 34 puta $(69,39 \%)$ nije podsjetila djecu na pravila ponašanja i 30 puta $(61,22 \%)$ nije jasno izrazila svoja očekivanja glede poželjnoga ponašanja djece te 30 puta $(62,5 \%)$ nije 
pohvalila poželjno ponašanje djece.

Iako u refleksiji odgojiteljica navodi kako su djeci pravila iznimno važna i daju im osjećaj sigurnosti, smatra kako konstantno podsjećanje djece na pravila ponašanja ograničava razvoj dječje samokontrole. Odgojiteljica dodaje kako se pravila ponašanja usvajaju na početku pedagoške godine, a u vrijeme provedbe istraživanju pravila su već usvojena i ne treba ih često ponavljati te ističe kako je najvrjednije kada djeca jedno drugoga podsjete na pravila ponašanja. Od odgojitelja se očekuje da ravnopravno reagira na dječje potrebe, osjećaje i ponašanja, uvažavajući pritom individualne razlike između djece. Jasnim isticanjem pravila koja vrijede jednako za svu djecu, odgojitelji će izražavati želju za pravednošću i stvarati pozitivno socijalno ozračje u skupini (Katz, McClellan, 1999).

Odgojiteljica smatra kako je pohvalu potrebno zavrijediti i da se dijete pohvaljuje kada je nešto posebno dobro napravilo ili svladalo određenu vještinu na način: Dobro si to napravio! Zanimljivo mi je to što radiš! ili usmenom pohvalom pred skupinom jer to djeci mnogo znači. S pohvalama odgojitelji trebaju biti vrlo oprezni, s obzirom na to da opetovano nagrađivanje/pohvaljivanje određene djece može obeshrabriti one koji se trude i napreduju, ali ne savladavaju određene socijalne vještine (Logue, 2007).

Prema protokolu praćenja odgojiteljica je u svim situacijama, dakle 14 puta (100\%), razgovarala s djecom koja su bila u sukobu, a nije izricala kazne. Djeca od četvrte do osme godine nisu sigurna u poruke koje im odgojitelji žele poručiti kažnjavanjem ili vikanjem (Zambarano, 1991 prema Logue, 2007), već je, kako navodi i odgojiteljica tijekom refleksije, važnije da dijete shvati kako nije ispravno postupilo i kako se drugi zbog toga osjećaju. Djeca kaznu doživljavaju kao nepoštenu i nezasluženu (Brophy, 1986 prema Logue, 2007), a sukladno tome, odgojiteljica kaznu ne smatra odgojnom, a samu izloženost sukobu i razgovoru o istome smatra svojevrsnom kaznom. Djeci je potrebna jasna i pažljiva komunikacija s odraslima (Logue, 2007), a odgojiteljica navodi kako nastoji s djecom razgovarati o nastaloj situaciji, ukazati na problem ili ih potaknuti da sami spoznaju u čemu su pogriješili, poticati ih na razmišljanje o vlastitim postupcima, dopustiti da malo kasnije pričaju o tome jer djeca često nisu ni svjesna da su pogriješila. Kaznama, kao što je izdvajanje iz grupe ili igre, odgojitelji gube priliku za podučavanje 
socijalnih vještina. Odgojiteljica je međutim istaknula kako postoje iznimne situacije u kojima je potrebno izdvojiti dijete iz grupe prijatelja s kojima se igra, kada se ono jako uzbudi ili ako postoji mogućnost fizičkoga nasrtanja na drugu djecu.

U refleksiji na rezultate, prema kojima je 34 puta $(89,47 \%)$ dala prijedloge u socijalnim interakcijama djece, odgojiteljica je navela kako djeci daje prijedloge u provođenju grupnih zadataka, ali jednako tako, nastoji im što češće omogućiti autonomiju jer na taj način uče biti odgovorni. Djeca se uče razboritosti i odgovornosti u situacijama u kojima im se daje mogućnost da samostalno donose odluke i služe se zdravim razumom, umjesto da odgojitelj donosi odluke umjesto njih (Katz, McClellan, 1999).

\section{Produbljivanje socijalnoga razumijevanja}

Socijalno razumijevanje uključuje komponente koje čine djelotvornu socijalnu interakciju (prepoznavanje i razumijevanje tuđih osjećaja, pokretanje i održavanje interakcije i sl.), a odgojitelji mogu produbljivati socijalno razumijevanje djece ovim strategijama: skretanje pozornosti djece na tuđe osjećaje i interese, postavljanje pitanja sa zanimanjem za dječje mišljenje, uvažavanje dječjih zamisli, poticanje empatije i altruizma, poticanje alternativnih interpretacije tuđeg ponašanja, poticanje djece na otkrivanje i razgovor o zajedničkim interesima.

Tablica 2. Korištenje strategija odgojiteljice za produbljivanje socijalnoga razumijevanja

\begin{tabular}{|l|l|l|l|l|l|}
\hline \multicolumn{2}{|c|}{ Čestica } & \multicolumn{1}{|c|}{$\begin{array}{c}\text { 8:35 } \\
\text { (vrijeme } \\
\text { doručka) }\end{array}$} & $\begin{array}{c}\text { 9:20 } \\
\text { (vrijeme } \\
\text { jutarnjega } \\
\text { kruga) }\end{array}$ & $\begin{array}{c}\text { 10:05 } \\
\text { (ponuda } \\
\text { materijala i } \\
\text { aktivnosti) }\end{array}$ & Ukupno \\
\hline $\begin{array}{l}\text { Skreće pozornost } \\
\text { na tuđe osjećaje } \boldsymbol{i} \\
\text { interese (1) }\end{array}$ & $\mathrm{Da}$ & $8(32 \%)$ & $11(44 \%)$ & $6(24 \%)$ & $25(100 \%)$ \\
\cline { 2 - 7 } $\begin{array}{l}\text { Postavlja pitanja } \\
\text { sa zanimanjem za } \\
\text { dječje mišljenje }(7)\end{array}$ & $\mathrm{Ne}$ & $10(35,71 \%)$ & $9(32,14 \%)$ & $9(32,14 \%)$ & $28(100 \%)$ \\
\cline { 2 - 7 } $\begin{array}{l}\text { Ua } \\
\text { Uvažava dječje } \\
\text { zamisli (8) }\end{array}$ & $\mathrm{Ne}$ & $6(54,55 \%)$ & $3(27,27 \%)$ & $2(18,18 \%)$ & $11(100 \%)$ \\
\cline { 2 - 7 } & $\mathrm{Ne}$ & $11(27,5 \%)$ & $17(42,5 \%)$ & $12(30 \%)$ & $40(100 \%)$ \\
\hline
\end{tabular}




\begin{tabular}{|l|l|l|l|l|l|}
\hline \multirow{2}{*}{$\begin{array}{l}\text { Potiče empatiju } \boldsymbol{i} \\
\text { altruizam (16) }\end{array}$} & $\mathrm{Da}$ & $4(21,05 \%)$ & $11(57,89 \%)$ & $4(21,05 \%)$ & $19(100 \%)$ \\
\cline { 2 - 6 } & $\mathrm{Ne}$ & $7(43,75 \%)$ & $6(37,5 \%)$ & $3(18,75 \%)$ & $16(100 \%)$ \\
\hline $\begin{array}{l}\text { Potiče alternativne } \\
\text { interpretacije tuđeg } \\
\text { ponašanja (17) }\end{array}$ & $\mathrm{Da}$ & $5(33,33 \%)$ & $7(46,67 \%)$ & $3(20 \%)$ & $15(100 \%)$ \\
\cline { 2 - 6 } & $\mathrm{Ne}$ & $4(28,57 \%)$ & $5(35,71 \%)$ & $5(35,71 \%)$ & $14(100 \%)$ \\
\hline $\begin{array}{l}\text { Potiče djecu na } \\
\text { otkrivanje i razgovor } \\
\text { ozajedničkim } \\
\text { interesima (18) }\end{array}$ & $\mathrm{Da}$ & $3(18,75 \%)$ & $10(62,5 \%)$ & $3(20 \%)$ & $16(100 \%)$ \\
\cline { 2 - 6 } & $\mathrm{Ne}$ & $15(42,86 \%)$ & $9(25,71 \%)$ & $11(31,43 \%)$ & $35(100 \%)$ \\
\hline
\end{tabular}

Prema protokolu praćenja, odgojiteljica 28 puta $(52,83 \%)$ nije skrenula pozornost djece na osjećaje i interese druge djece, a u refleksiji objašnjava kako ponekad treba reagirati, a ponekad ne, već dati priliku djeci da sami zaključuju. Međutim, kod djece u vrtiću potrebno je poticati razvoj sposobnosti predviđanja tuđih osjećaja, razvijati svijesti o interesima drugih i jačati empatijske osjećaje i postupke djece. Cilj skretanja pozornosti djece na tuđe osjećaje i interese je razvijanje sposobnosti predviđanja reakcija i osjećaja drugih u određenim situacijama te produbljivanje razumijevanja i upoznavanje vršnjaka (Katz, McClellan, 1999). Također, odgojitelj je svojim ponašanjem model koji će djeca slijediti. S ciljem poticanja djece, sam odgojitelj može raspraviti s djecom o svojim razmišljanjima glede predviđanja tuđih osjećaja i interesa (Katz, McClellan, 1999). Time će pokazati kako obraća pozornost na njihove interese i osjećaje, a odnosi u kojima odgojitelji reagiraju na dječje emocionalne znakove pridonose smanjenju stresa kod djece (Nagel, 2012 prema Kirk, MacCallum, 2017).

Odgojiteljica je 41 put $(78,85 \%)$ postavila pitanje sa zanimanjem za dječje mišljenje i 40 puta (90,91\%) uvažila dječje zamisli. U refleksiji je odgojiteljica naglasila kako joj je važno (i zanimljivo) čuti dječje mišljenje i često nastoji postavljati pitanja kojima kod djece provocira izražavanje misli, stavova i želja, što joj pomaže u kreiranju aktivnosti. Ističe kako nastoji ohrabrivati djecu da slobodno izražavaju svoje stavove i time ostvaruju svoja dječja prava. Smatra kako je važno da odgojitelj uvažava dječje mišljenje jer na taj način djeca stječu povjerenje u odgojitelja. Kvalitetan odgojno-obrazovni pristup odgojitelja temeljen je na cjelovitome razumijevanju djeteta, njegovih zamisli, perspektiva, pretpostavki i načina razumijevanja okoline (Slunjski, 2008), a praćenjem aktivnosti djeteta, 
njegovoga izražavanja i mišljenja, odgojitelj određuje aktualne točke njegovoga razvoja (Hajdin, 2010) na temelju kojih kreira vlastito odgojnoobrazovno djelovanje.

Prema protokolu praćenja odgojiteljica je 19 puta (54,29\%) poticala empatiju i altruizam kod djece, dok 16 puta $(45,71 \%)$ to nije učinila. Odgojiteljica je u refleksiji uvidjela kako je poticanje empatije i altruizma najizraženije u jutarnjem krugu, što objašnjava kako je tijekom vođene aktivnosti važno pozorno slušati što drugi govore, potrebno mnogo intervenirati. Svakodnevne aktivnosti u vrtiću prilike su za jačanje empatije i altruizma, a posebice situacije koje podrazumijevaju naizmjenično sudjelovanje. Važno je da odgojitelji pomognu djetetu u produbljivanju razumijevanja posljedica vlastitih postupaka na drugu djecu (Katz, McClellan, 1999).

Prema protokolu praćenja odgojiteljica je 15 puta $(51,74 \%)$ poticala alternativne interpretacije tuđega ponašanja, dok 14 puta $(48,28 \%)$ to nije učinila. Tijekom refleksije odgojiteljica je iskazala svjesnost činjenice kako u ovome obliku manje intervenira, ali smatra kako nije ni potrebno često reagirati, s obzirom na to da djeca nerijetko sama dođu do pacifističke interpretacije tuđega neprimjerenoga ponašanja. Kako bi se smanjilo etiketiranje ponašanja drugih, važno je da odgojitelj objasni djetetu kako između njih postoje razlike u navikama, ponašanjima ili običajima te da im pomogne u osmišljavanju alternativnih tumačenja tuđih namjera (Katz, McClellan, 1999). Odgojiteljica je 16 puta (31,37\%) poticala djecu na otkrivanje i razgovor o zajedničkim interesima, dok 35 puta (68,63\%) to nije učinila, s obzirom na to da jedino tijekom jutarnjega kruga postavlja pitanja kojima se od djece očekuje izražavanje vlastitih interesa, dok tijekom ostalih aktivnosti dopušta da sami otkrivaju zajednička obilježja. Zajednički interes ili zanimanje djece za iste stvari može biti početak razgovora, zajedništva ili prijateljstva između djece, a prilika za to mogu biti svakodnevne aktivnosti u vrtiću (Katz, McClellan, 1999) koje je potrebno iskoristiti.

\section{Pospješivanje interaktivnih umijeća}

Jedan od najvažnijih čimbenika za optimalan kognitivni razvoj djeteta je socijalna interakcija (Rogoff, 1990 prema Katz, McClellan, 1999), 
a jedna od glavnih zadaća odgojitelja je osiguravanje prilika za sudjelovanje u smislenim interakcijama djeteta s vršnjacima. Strategije kojima odgojitelji mogu poticati kod djece razvoj interaktivnih umijeća jesu: poticanje djece da izraze ono što žele, poticanje suradnje i predlaganje rečenica za poticanje suradnje, ohrabrivanje djeteta da se uključi u igru s drugom djecom, poticanje isprika, osiguravanje alternative tužakanju, poticanje djece na strpljenje, predlaganje tema za razgovor, poticanje djece da postavljaju pitanja te služenje uljudnim frazama u razgovoru s djecom.

Tablica 3. Korištenje strategija odgojiteljice za pospješivanje interaktivnih umijeća

\begin{tabular}{|c|c|c|c|c|c|}
\hline \multicolumn{2}{|l|}{ Čestica } & $\begin{array}{c}8: 35 \\
\text { (vrijeme } \\
\text { doručka) }\end{array}$ & $\begin{array}{c}9: 20 \\
\text { (vrijeme } \\
\text { jutarnjega } \\
\text { kruga) }\end{array}$ & $\begin{array}{c}10: 05 \\
\text { (ponuda } \\
\text { materijala i } \\
\text { aktivnosti) }\end{array}$ & Ukupno \\
\hline \multirow{2}{*}{$\begin{array}{l}\text { Potiče djecu da } \\
\text { izraze ono što žele } \\
\text { (9) }\end{array}$} & $\mathrm{Da}$ & $+(35 \%)$ & $15(3$ & $11(2)$ & $40(100 \%)$ \\
\hline & $\mathrm{Ne}$ & $2(33,3$ & $2(33$ & $2(33$ & o) \\
\hline \multirow{2}{*}{$\begin{array}{l}\text { Potiče djecu na } \\
\text { suradnju (10) }\end{array}$} & $\mathrm{Da}$ & $15(32)$ & $17(37$ & 0) & \\
\hline & $\mathrm{Ne}$ & 3( & $2(3$ & & \\
\hline \multirow{2}{*}{$\begin{array}{l}\text { Predlaže rečenice za } \\
\text { poticanje suradnje } \\
\text { (11) }\end{array}$} & $\mathrm{Da}$ & & & & \\
\hline & $N$ & 14 & & & \\
\hline \multirow{2}{*}{$\begin{array}{l}\text { Ohrabruje dijete da } \\
\text { se ukljuci u igru s } \\
\text { drugom djecom (12) }\end{array}$} & $\mathrm{Da}$ & $2(14,29 \%)$ & $7(50 \%)$ & $5(35,71 \%)$ & 14 \\
\hline & 19 & ) & 1 & 8 & 30 \\
\hline \multirow{2}{*}{ Potiče isprike (13) } & $\mathrm{Da}$ & $1(1$ & & & \\
\hline & $\mathrm{Ne}$ & $8(4$ & 6( & & $\%)$ \\
\hline \multirow{2}{*}{$\begin{array}{l}\begin{array}{l}\text { Osigurava } \\
\text { alternativu } \\
\text { tužakanju (14) }\end{array} \\
\end{array}$} & $\mathrm{Da}$ & 2( & & & $0 \%)$ \\
\hline & $\mathrm{Ne}$ & 1 & & & $\%)$ \\
\hline \multirow{2}{*}{$\begin{array}{l}\text { Potiče djecu na } \\
\text { strpljenje (15) }\end{array}$} & $\mathrm{Da}$ & $13(30,23$ & $19(44,1$ & $11(25,58$ & $43(100 \%)$ \\
\hline & $\mathrm{Ne}$ & & & & \\
\hline \multirow{2}{*}{$\begin{array}{l}\text { Predlaže teme za } \\
\text { razgovor (19) }\end{array}$} & $\mathrm{Da}$ & & & & 23 \\
\hline & $\mathrm{Ne}$ & $\%)$ & $9(29$, & $8(25$ & $00 \%)$ \\
\hline \multirow{2}{*}{$\begin{array}{l}\text { Potiče djecu da } \\
\text { postavljaju pitanja } \\
\text { (20) }\end{array}$} & $\mathrm{Da}$ & $10(27,78 \%)$ & $16(44,44 \%)$ & $10(27,78 \%)$ & $36(100 \%)$ \\
\hline & $\mathrm{Ne}$ & $8(47,06 \%)$ & $4(23,53 \%)$ & $5(29,41 \%)$ & $17(100 \%)$ \\
\hline \multirow{2}{*}{$\begin{array}{l}\text { Služi se uljudnim } \\
\text { frazama u } \\
\text { razgovoru s djecom } \\
(21)\end{array}$} & $\mathrm{Da}$ & $20(33,33 \%)$ & $20(33,33 \%)$ & $20(33,33 \%)$ & $60(100 \%)$ \\
\hline & $\mathrm{Ne}$ & $0(0 \%)$ & $0(0 \%)$ & $0(0 \%)$ & $0(0 \%)$ \\
\hline
\end{tabular}


Prema protokolu praćenja odgojiteljica je 40 puta (86,96\%) poticala djecu da izraze ono što žele, a u refleksiji je naglasila kako se uvijek trudi potaknuti djecu da izraze svoje želje, postavlja pitanja i pozorno ih sluša. Djeca se na taj način uče zauzimati za sebe i svjesno zadovoljavati svoje potrebe. Smatra kako svaki odgojitelj mora vidjeti, čuti i poticati djecu da sama izražavaju svoje potrebe, što je u skladu s činjenicom kako verbalna umijeća djece imaju najvažniju ulogu u socijalnim interakcijama (Katz, McClellan, 1999).

Prema protokolu praćenja odgojiteljica je 45 puta $(88,24 \%)$ poticala djecu na suradnju i 10 puta $(19,23 \%)$ predložila rečenice za poticanje suradnje među djecom.

Za uključivanje u suradničke aktivnosti, dijete mora ovladati verbalnim interaktivnim umijećima (Katz, McClellan, 1999), a odgojitelji kroz priče i razgovore pružaju priliku djeci da uče i uvježbavaju potrebne socijalne vještine (Logue, 2007). Odgojitelji potiču kod djece osjećaj pripadnosti skupini putem grupnih rituala, sastanaka ili krugova, proslavama grupnih postignuća i iskrenih razgovara sa svakim djetetom (Logue, 2007). Tijekom refleksije odgojiteljica je komentirala kako u organizaciji prostora kakvu imaju u vrtiću (prostor podijeljen na centre aktivnosti) nije potrebno posebno poticati djecu na suradnju jer to i sam prostor čini.

U refleksiji je odgojiteljica istaknula da je potrebno predlagati rečenice za poticanje suradnje samo dok se djeca ne izvježbaju, a to je uglavnom na početku pedagoške godine. Trenutno potiče samo mlađu djecu, a kasnije to sami dobro odrađuju. Odgojiteljica smatra kako djeca uče čineći i uče od druge djece mnogo više nego od odraslih, čemu posebno pogoduju dobno mješovite skupine, u kojima mlađi uče od starijih, koji su više godina u vrtiću. Kada se dogodi neki problem u suradnji, odgojiteljica navodi da djeca traže pomoć i ispričaju u čemu je problem, a odgojiteljica nastoji predložiti izjave ili metode koje bi im mogle koristiti za daljnji nastavak suradničke aktivnosti. Važno je da odgojitelji omoguće djeci ravnopravno sudjelovanje u rješavanju problema sa svojim vršnjacima, eventualno poticati raspravu pitanjima ili idejama sukladnim dječjem razgovoru (Kirk, MacCallum, 2017).

Prema protokolu praćenja odgojiteljica je 14 puta (28\%) ohrabrila 
dijete da se uključi u igru s drugom djecom, dok 36 puta (72\%) to nije učinila. Odgojitelj može svojim ponašanjima, kao što su: označavanje uloge ili nositelja uloge, davanje informacija, pokazivanje postupka, davanje instrukcija, upoznavanje s pravilima igre, ispravljanje netočnih spoznaja, pohvaljivanje djece, davanje novih sredstava i reorganiziranje prostora te uključivanje besposlenoga djeteta (Šagud, 2002) poticati dječju igru. Mnoge socijalne interakcije djece u vrtiću tiču se pokušaja djeteta da se pridruži skupini djece koja se igra (Katz, McClellan, 1999). Odgojitelj potiče djecu na ovladavanje verbalnih interaktivnih umijeća kojima će pristupiti grupi djece koja se igra. Odgojiteljica je komentirala da se djeca sama uključuju u igru s drugom djecom, a ona ih uglavnom potiču na početku pedagoške godine. Samo djecu koja su bezvoljna, bez ideje i koja se ne osjećaju dobro treba dodatno poticati. Također, navodi da neka djeca uglavnom izabiru samostalnu ili paralelnu igru. Ipak, smatra kako je dobro djecu poticati da se uključuju u igru s drugom djecom jer je igra djeci najprirodniji i najlakši put usvajanja socijalnih vještina.

Odgojiteljica 19 puta (76\%) nije poticala isprike među djecom, što u refleksiji objašnjava time kako je lijepo da se dijete ispriča ako zna zašto. Međutim, ukoliko je isprika površna i bez razumijevanja posljedica neprihvatljivoga ponašanja, tada ona nema smisla već samo narušava kontinuitet $\mathrm{u}$ dječjoj igri. Socijalne konvencije omogućuju mirnu i djelotvornu interakciju između ljudi (Katz, McClellan, 1999), a isprika je dio kulturnoga standarda (Bašić, Žižak, 1992). Odgojitelji trebaju pomoći djetetu da shvati kada njegovo ponašanje nije bilo u skladu s dogovorenim pravilima i kako se zbog toga treba ispričati. Ukazivanjem na konkretnu posljedicu dječjega ponašanja, potičemo razvoj empatije i altruizma kod djece.

Prema protokolu praćenja odgojiteljica je 10 puta $(76,92 \%)$ osigurala alternativu tužakanju i 43 puta $(89,58 \%)$ potaknula djecu na strpljenje. Tužakanjem djeca često nastoje privući pozornost odgojitelja. Odgojitelji u tim situacijama mogu savjetovati dijete da samo podsjeti ostale na dogovorena pravila ponašanja, ali pritom odgovorno pratiti dječje aktivnosti, s obzirom na to da predškolska djeca najčešće ne mogu procijeniti ozbiljnost ili eventualnu opasnost u određenoj situaciji (Katz, McClellan, 1999). Iz razgovora s odgojiteljicom saznajemo kako nije 
pobornik tužakanja i potiče djecu da kažu kad se njima nešto dogodi, a ne kad se dogodi drugima. U vrijeme ispitivanja, situacija tužakanja bilo je vrlo malo.

Problem naizmjeničnoga sudjelovanja najčešći je razlog tužakanja kod djece u vrtiću, s obzirom na to da velik dio socijalnih aktivnosti u vrtiću zahtijeva čekanje na red. Odgojitelji mogu ohrabriti dijete da se pridruži skupini i zatraži svoj red. Ako se radi o nepopustljivome djetetu koje ne dozvoljava drugima sudjelovanje, odgojitelji mogu jednostavnim objašnjenjem potaknuti dijete da ustupi aktivnost drugome (Katz, McClellan, 1999). Odgojiteljica je istaknula važnost strpljenja u svakodnevnome životu i značaj učenja strpljivosti od vrtićkih dana. Najviše djecu potiče na strpljivost u vrijeme jutarnjega kruga ili početnih jutarnjih aktivnosti, a manje u kasnijim aktivnostima tijekom dana. Tijekom doručka potiče strpljivost kod uzimanja pribora, hrane i slično.

Prema protokolu praćenja odgojiteljica je 23 puta $(42,59 \%)$ predložila temu za razgovor, dok 31 puta $(57,41 \%)$ to nije učinila. Odgojitelji u radu s djecom otkrivaju djeci zanimljive teme, potiču ih na razmišljanje, izražavanje, međusobnu razmjenu misli, ideja i iskustva. Dakle, zadatak odgojitelja je kreirati poticajno socijalno okruženje koje će omogućiti djeci različitih kompetencija sudjelovanje u interakcijama (Slunjski, 2008). Tijekom dječjega razgovora nije potrebno prekidati djecu, već promatrati, usvojiti pravila njihove komunikacije i iskoristiti ih za ulazak u razgovor. $\mathrm{Na}$ taj način djeca ne stječu dojam da je odgojitelj preuzeo kontrolu nad njihovom interakcijom (Kirk, MacCallum, 2017). Odgojiteljica ističe kako je važno slijediti interese djece, prepoznavati njihove teme za razgovor, a ne nametati svoje. Najčešće predlaže teme za razgovor tijekom jutarnjega kruga, što smatra očekivanim.

Prema protokolu praćenja odgojiteljica je 36 puta $(67,92 \%)$ poticala djecu da postavljaju pitanja, dok 17 puta $(32,08 \%)$ to nije učinila. Odgojiteljica u većini slučajeva potiče djecu da postavljaju pitanja i da budu znatiželjni jer smatra to iznimno važnim za socijalni razvoj djece. Svrha poticanja djece na postavljanje pitanja je stvaranje spontane navike komuniciranja, stjecanje sklonosti za razmjenu misli, osjećaja i iskustava (Katz, McClellan, 1999).

Prema protokolu praćenja odgojiteljica se 60 puta (100\%) služila 
uljudnim frazama u razgovoru s djecom. U refleksiji je odgojiteljica izrazila zadovoljstvo ovim rezultatom. U radu s djecom uvijek se služi uljudnim frazama i često upotrebljava „četiri najvažnije male riječi“: molim, hvala, izvoli, oprosti. U razgovoru s djecom se uvijek trudi pričati hrvatskim standardnim jezikom, a ne na dijalektu jer smatra da odgojitelj mora biti uzor djetetu u govornome izražavanju. Odgojitelj je model za razvoj prosocijalnih ponašanja djece u vrtiću, stoga je važno poštivati kulturni standard, koji uključuje: zahvaljivanje, pozdravljanje, ispričavanje, zamolbu i slično (Bašić, Žižak, 1992).

Nakon pregledanih rezultata odgojiteljica je navela da se razvija $u$ skladu s grupom, kako joj je ovaj uvid bio jako koristan jer je mogla vidjeti na što više, a na što manje reagira. Na temelju rezultata mogla je steći uvid kako cijela skupina funkcionira. Istaknula je kako sve ovisi o razdoblju godine u kojem se promatra. Smatra da bi bili mnogo drugačiji rezultati da je istraživanje provedeno na početku pedagoške godine, kada je bilo više poučavanja, više ponavljanja pravila i poticanja nove djece na igru, a sada se ubiru plodovi rada s početka godine.

Rezultati ovoga istraživanja mogu biti poticaj odgojiteljima za promišljanje o vlastitim socijalnim kompetencijama i strategijama koje koriste u radu s djecom, kao i motivacija za poboljšanje cjelokupnoga odgojno-obrazovnoga rada s djecom u vrtiću, a posebice za osvještavanje koliko je socijalni razvoj djece važan i koliko oni, kao odgojitelji, mogu svojim strategijama i svojim ponašanjem utjecati na razvoj dječjih socijalnih kompetencija.

Ograničenje istraživanja je premali uzorak ispitanika te bi za objektivniji uvid u strategije kojima se koriste odgojitelji u facilitiranju socijalnih interakcija djece u vrtiću valjalo istraživanje ponoviti s većim brojem ispitanika, koji bi se razlikovali prema općim podacima odgojitelja.

Ipak, smatramo da su mjerni instrumenti najveća vrijednost ovoga rada: Protokol nesudioničkog opažanja i Polustruturirani upitnik izrađeni za potrebe istraživanja, koji mogu biti pomoć odgojiteljima u osvještavanju i unapređenju svojih strategija u radu s djecom te stručnim suradnicima vrtića, koji mogu pomoći odgojiteljima u unapređenju njihovih vještina.

Preporuka koja proizlazi nakon provedenoga istraživanja jest osmišljavanje tematskih radionica za unapređenje strategija odgojitelja 
za facilitiranje socijalnih interakcija djece u vrtiću s ciljem pojačavanja socijalnih kompetencija djece.

\section{Zaključak}

U razvoju dječjih socijalnih kompetencija veliku ulogu imaju odgojitelji u vrtiću koji svojim primjerom ponašanja i strategijama potiču i unapređuju socijalni razvoj djeteta. U ovome je istraživanju cilj bio utvrditi kojim se strategijama koristi odgojiteljica $u$ facilitiranju socijalnih interakcija djece u vrtiću. Rezultati istraživanja pokazuju da odgojiteljica razgovara s djecom koja su u sukobu, ne koristi se kaznama, daje prijedloge u socijalnim interakcijama, a ne naredbe, postavlja pitanja sa zanimanjem za dječje mišljenje, uvažava dječje zamisli i potiče djecu na izražavanje svojih želja, potiče djecu na suradnju i predlaže rečenice za poticanje suradnje, osigurava alternativu tužakanju, potiče djecu na strpljenje, potiče altruizam i empatiju, potiče alternativne interpretacije tuđega ponašanja, potiče djecu da postavljaju pitanja i koristi se uljudnim frazama u razgovoru s djecom. Drugim strategijama koje su se pratile odgojiteljica se koristila manje. U refleksiji na dobivene rezultate istraživanja odgojiteljica je izrazila zadovoljstvo rezultatima, ali i uočila priliku za unapređenje svojih strategija rada u skupini.

Za unapređenje odgojno-obrazovnoga rada s djecom potrebno je da odgojitelj osvijesti koje strategije upotrebljava u facilitiranju socijalnih interakcije između djece, koje su prednosti njihovoga korištenja, kojim se strategijama ne koristi u dovoljnoj mjeri i raditi na njihovom implementiranju u odgojno-obrazovnu praksu, a smatramo da im ovaj rad može pomoći u osobnom unaprjeđenju vlastitih strategija za facilitiranje dječjih socijalnih odnosa.

\section{Literatura}

BAŠIĆ, J., ŽIŽAK, A., 1992, Teorijske postavke integralne metode u radu s predškolskom djecom i njihovim roditeljima, Defektologija, 28(1-2), 197-213. 
BERK, L. E., 2008, Psihologija cjeloživotnog učenja, Naklada Slap, Jasterbarsko.

BRAJŠA-ŽGANEC, A., SLUNJSKI, E., 2007, Socioemocionalni razvoj u predškolskoj dobi: povezanost razumijevanja emocija i prosocijalnog ponašanja, Društvena istraživanja, 16(3), 89, 477-496.

BRDAR, I., 1994, Socijalna kompetencija i neki aspekti ličnosti, Godišnjak Odsjeka za Psihologiju, 3, 11-19.

DEMIRKAYA, P. N., BAKKALOGLU, H., 2015, Examining the Student-Teacher Relationships of Children Both With and Without Special Needs in Preschool Classrooms, Educational Sciences: Theory \& Practice, 15(1), 159-175.

HAJDIN, Lj., 2010, Od strukturiranih odgojno-obrazovnih programa do kurikuluma. U: Znanstvena monografija. Interdisciplinarni pristup učenju - put ka kvalitetnijem obrazovanju djeteta. Sveučilište u Zagrebu Učiteljski fakultet, Zagreb, 113-122.

IVON, H., SINDIK, J., 2008, Povezanost empatije i mašte odgojitelja s nekim karakteristikama ponašanja i igre predškolskog djeteta, Magistra Iadertina, 3(3), 21-38.

JANKOVIĆ, J., REZIĆ, L., PINTUR, B., 1995, Evaluacija provedbe programa odgoja za mir u D. C. „Matija Gubec“ u Zagrebu, Društvena istraživanja, 15(4), 1, 57-69.

KATZ, L. G., MCCLELLAN, D. E., 1999, Poticanje razvoja dječje socijalne kompetencije, Educa, Zagreb.

KIRK, G., MACCALLUM, J., 2017, Strategies that support kindergarten children's social and emotional development: One teacher's approach, Australasian Journal of Early Childhood, 42(1), 85-93.

LEPIČNIK VODOPIVEC, J., 2011, Cooperative learning and support strategies in the kindergarten, Metodički obzori, 12(6), 2, 81-91.

LOGUE, M. E., 2007, Early Childhood Learning Standards: Tools for Promoting Social and Academic Success in Kindergarten, Children \& Schools, 29(1), 35-43.

LUČIĆ, K., 2007, Odgojiteljska profesija u suvremenoj odgojnoobrazovnoj ustanovi, Odgojne znanosti, 9(1), 135-150.

MATIJEVIĆ, M., BILIĆ, V., OPIĆ, S., 2016, Pedagogija za učitelje i nastavnike, Školska knjiga, Zagreb. 
MLINAREVIĆ, V., TOMAS, S., 2010, Partnerstvo roditelja i odgojitelja - čimbenik razvoja socijalne kompetencije djeteta, Magistra Iadertina, 5(5), 143-158.

SLUNJSKI, E., 2008, Dječji vrtić zajednica koja uči - mjesto dijaloga, suradnje i zajedničkog učenja, Spektar Media, Zagreb.

SLUNJSKI, E., 2013, Kako djetetu pomoći da ...stječe prijatelje $i$ razvija socijalne vještine, Element, Zagreb.

ŠAGUD, M., 2002, Odgajatelj u dječjoj igri, Školske novine Zagreb.

TATKOVIĆ, N., DIKOVIĆ, M., TATKOVIĆ, S., 2016, Pedagoškopsihološki aspekti komunikacije, Sveučilište Jurja Dobrile u Puli, Pula.

ŽIŽAK, A., 2003, Konceptualni aspekti učenja socijalnih vještina, Kriminologija i socijalna integracija, 11(2), 107-115.

\section{Strategie di insegnamento prescolare nel facilitare l'integrazione sociale dei bambini}

I bambini adottano le abilità sociali necessarie per una efficace interazione sociale all'interno delle loro famiglie sin dall'inizio della loro vita, mentre gli insegnanti della scuola dell'infanzia organizzano attività didattiche di programma creando un'atmosfera stimolante e piacevole nella quale vengono messi in atto i processi di apprendimento. Utilizzando strategie educative l'insegnante incoraggia le interazioni sociali tra i bambini della scuola dell'infanzia, dimostrando un modello di comportamento per l'apprendimento e lo sviluppo delle loro abilità sociali.

Lo scopo di questa ricerca è di determinare le strategie utilizzate dagli insegnanti per facilitare l'interazione tra i bambini della scuola dell'infanzia. Il sondaggio è stato condotto per i mesi di febbraio, marzo, aprile e maggio del 2017, sul campione di un insegnante della scuola d'infanzia „Olga Ban“ di Pisino. Utilizzando due strumenti di misura: il protocollo di osservazioni non partecipate, sviluppato per questo studio, con la finalità di definire le strategie dell'insegnante e il questionario semi strutturato mirato a cogliere riflessioni dell' insegnante stesso. Secondo l'accordo con l'insegnante, l'osservatore si è incontrato con il gruppo una ventina di volte in tre diversi momenti temporali della durata di 
cinque minuti: 8:35 (ora di colazione), 9:20 (cerchio del mattino), 10:05 (distribuzione di materiali e attività) osservando e annotando le strategie utilizzate dall'insegnante. In seguito i dati di protocollo di comportamento dell'insegnante sono stati elaborati e analizzati, l'insegnante stessa è stata intervistata con l'accento sulle sue riflessioni sui risultati raccolti.

I risultati del sondaggio mostrano che l'insegnante nella maggior parte delle situazioni interviene parlando con i bambini in conflitto, non punisce e piuttosto di comandare dà suggerimenti pratici nelle interazioni sociali; ponendo domande dimostra interesse per il loro pensiero, considera le loro idee, incoraggiandoli ad esprimere i propri desideri e a collaborare, suggerisce frasi per incoraggiare la collaborazione, fornendo un'alternativa al rubacchiare, incoraggiando i bambini ad essere pazienti, incoraggiando il loro altruismo e l'empatia, appoggiando le interpretazioni alternative di comportamenti altrui, incoraggiando i bambini a porre domande usando frasi educate e parlando con loro.

Durante la seconda fase, quella della riflessione, l'insegnante ha espresso soddisfazione per i metodi utilizzati evidenziando i benefici della ricerca per ulteriori approfondimenti e l'apprendimento delle attività lavorative e di pianificazione.

Parole chiave: Insegnante di scuola dell'infanzia, strategia, interazione sociale, abilità sociali

\section{Strategies used by preschool teachers in facilitating social interaction among children in kindergarten}

Children adopt the social skills required for effective social interaction within their families from the very beginning of their lives, while preschool teachers organize program activities and create a stimulating and pleasant atmosphere in which they can learn and practice. By utilizing educational strategies, the teacher encourages social interaction among kindergarteners and also provides a model for the development of their social skills by demonstrating his/her own characteristics.

The aim of this research is to determine the strategies used by teachers to facilitate social interaction among kindergarteners. This 
survey was conducted throughout February, March, April and May of 2017 using one sample: a preschool teacher in Olga Ban Kindergarten in Pazin. Two measuring instruments were used: the non-participatory observations protocol developed for the purpose of this study was used to record the teacher's strategies and also the semi structured questionnaire on the teacher's reflections. In arrangement with the teacher, the observer spent time with the group on approximately twenty occasions and in three different time points lasting for five minutes : 08:35 am (breakfast time), 09:20 am (morning circle), 10:05 am (distribution of materials and activities) and observed and noted the strategies used by the teacher. After the data from the teacher's behavior protocol had been processed and analyzed, the teacher herself was interviewed with focus on her reflections on the collected results.

The results show that a preschool teacher in most situations talks to children in conflict, does not punish them, suggests social interaction rather than a command, raises questions with an interest in a child's thinking, takes note of a child's ideas, encourages children to express their desires, encourages children to co-operate and suggests means to encourage co-operation, provides an alternative to snitching, encourages children to be patient, encourages altruism and empathy, encourages alternative interpretations of other behavior, encourages children to ask questions and use polite phrases when talking. During reflection, the preschool teacher expressed satisfaction with the methods used and highlighted the benefits of research for further work and planning activities

Key words: preschool teacher, strategy, social interaction, social skills 